\title{
Evaluation of the alpha-amylase inhibitory activity of Nepalese medicinal plants used in the treatment of diabetes mellitus
}

\author{
${\text { Karan } \text { Khadayat }^{1 \dagger}, \text { Bishnu P. Marasini }}^{1 \dagger}$, Hira Gautam', Sajani Ghaju ${ }^{1}$ and Niranjan Parajuli ${ }^{2^{*}}$ (D)
}

\begin{abstract}
Background: a-Amylase catalyses the hydrolysis of starch and ultimately producing glucose. Controlling the catalytic activity of this enzyme reduces glucose production in the postprandial stage, which could be a therapeutic benefit for people with diabetes. This study was conducted to evaluate a-amylase inhibition for utilizing the crude extracts of some medicinal plants traditionally used in Nepal for the treatment of diabetes and its related complications.

Methods: Microtiter plate approach has been used to assess inhibitory activities of in vitro a-amylase of methanolic extracts of thirty-two medicinal plants. A starch tolerance test was used in rats to investigate the in vivo study of the methanolic extract concerning glibenclamide as the positive control.

Results: Acacia catechu, Dioscorea bulbifera, and Swertia chirata exhibited inhibitory activity against a-amylase and with IC 50 values; $49.9,296.1$, and $413.5 \mu \mathrm{g} / \mathrm{mL}$, respectively. Kinetics study revealed that all the extracts displayed a mixed type of inhibition pattern, with $K_{i}$ values ranging from $26.6-204.2 \mu \mathrm{g} / \mathrm{mL}$. Free radical scavenging activity was again re-examined and found prominent in extracts of $A$. catechu. Likewise, A. catechu and S. chirata showed significant reduction of blood glucose concentration up to $30 \mathrm{~min}$ after oral dose of $250 \mathrm{mg} / \mathrm{kg}(\mathrm{F}(4,20)=4.1$, $p=.048)$, and $(F(4,20)=4.1, p=.036)$, respectively.

Conclusions: Enzymatic assay for a-amylase inhibition using extracts was successfully evaluated. Also, the in-vitro and in-vivo study model revealed that medicinal plants could be a potent source of a-amylase inhibition. So, they could serve as potential candidates for future drug development strategies for curing diabetes with minimal or no adverse side effects.
\end{abstract}

Keywords: Diabetes, a-Amylase, Acacia catechu, Oral starch tolerance test

\section{Background}

In Diabetes, the body cannot produce enough insulin or cannot use insulin and is diagnosed by observing raised levels of glucose in the blood. Among 7.7 billion total populations (2019), around 463 million adult people have diabetes with a global prevalence of $9.3 \%$ and may rise to $10.9 \%$ by 2045 . In 2019 , the prevalence rate of

\footnotetext{
* Correspondence: nparajuli@cdctu.edu.np

†Karan Khadayat and Bishnu P. Marasini contributed equally to this work.

${ }^{2}$ Central Department of Chemistry, Tribhuvan University, Kirtipur, Kathmandu, Nepal

Full list of author information is available at the end of the article
}

diabetes in Nepalese adults was observed to be $4 \%$ and accounted for approximately 696,900 sufferings and 11, 700 adult deaths due to diabetes [1]. In the medical term, diabetes is the endocrine-metabolic disorder. It is defined as fasting blood glucose equals to or higher than $7 \mathrm{mmol} / \mathrm{L}$ or on medication for raised blood glucose [2]. It is a complex disease delineate by disarray in carbohydrate, protein, and fat metabolism that aftermath in micro- and macro-vascular changes causing secondary complications [3]. These secondary complications include heart attack, stroke, kidney failure, leg amputation, vision loss, and nerve damages [4]. Maintaining stable

\section{Springer Open}

(๑) The Author(s). 2020 Open Access This article is licensed under a Creative Commons Attribution 4.0 International License, which permits use, sharing, adaptation, distribution and reproduction in any medium or format, as long as you give appropriate credit to the original author(s) and the source, provide a link to the Creative Commons licence, and indicate if changes were made. The images or other third party material in this article are included in the article's Creative Commons licence, unless indicated otherwise in a credit line to the material. If material is not included in the article's Creative Commons licence and your intended use is not permitted by statutory regulation or exceeds the permitted use, you will need to obtain permission directly from the copyright holder. To view a copy of this licence, visit http://creativecommons.org/licenses/by/4.0/. 
and lower blood glucose can be achieved by delaying glucose absorption through inhibition of carbohydratehydrolyzing enzymes, such as $\alpha$-glucosidase and $\alpha$ amylase in the digestive tract [5].

Among the different classes of the enzyme, $\alpha$-amylase ( $\alpha$-1, 4 glucan-4-glucanohydrolase; EC 3.2.1.1) belongs to hydrolases class and can be found in microbes, plants, and animals [6]. It is a metalloenzyme requiring at least one $\mathrm{Ca}^{2+}$ ion per enzyme molecule crucial for their activity and stability [7]. Porcine pancreatic $\alpha$-amylase shares $83 \%$ similarity with human pancreatic amylase and composed of 496 amino acid residues [8]. The $\alpha$ amylase is found in saliva and pancreatic juice [9], that hydrolyzes alpha-linked polysaccharide's alpha bonds like in starch and glycogen, resulting in glucose and maltose that could quickly enter the bloodstream [10]. It is the primary amylase type present in humans and other mammals. Inhibition of $\alpha$-amylase delays the digestion process by hampering the breakdown of starch in the intestine and hence can be utilized as an effective strategy for regulating hyperglycemic conditions [11].

For the regulation of blood glucose levels, different classes of drugs such as sulfonylureas, non-sulfonylureas secretagogues, biguanides, meglitinide, dipeptidyl peptidase 4 (DPP-4) inhibitors, sodium-glucose cotransporter (SGLT2) inhibitors, $\alpha$-glucosidase inhibitors, and thiazolidinediones (glitazones) are employed [10]. However, these drugs are associated with the lack of specificity and hence have been reported to cause several gastrointestinal side effects like cramping, flatulence, abdominal distention, and diarrhea [12]. In recent years, research on medicinal plants for managing diabetes has attracted scientists [13]. There are several advantages of natural herbal drugs such as reduction of risk of side effects, effectiveness with chronic conditions, widespread availability, and low cost [14]. Therefore, inhibitors of the $\alpha$-amylase enzyme, which are extracted from plants, could be emerging candidates to control hyperglycemia in diabetic patients $[15,16]$.

Azadirachta indica, Carum carvi, Tinospora sinensis, Vitex negundo, Acacia catechu, Ficus religiosa, Cirsium verutum, Mirabilis jalapa, Myrica esculenta, Nephrolepsis cordifolia, Rubus ellipticus, Zea mays, Asparagus racemosus, and Aloe vera are the most common and potent antidiabetic medicinal plants traditionally used in Nepal $[17,18]$. This research is focused mainly on type 2 diabetes, which is a chronic metabolic disease characterized primarily by insulin resistance in target tissue leading to hyperglycemia and, ultimately, malfunctions of the $\beta$-cells [19]. The aim of this study was in vitro screening the crude extracts of selected Nepalese medicinal plants for inhibitory activities against $\alpha$-amylase by microtiter plate-based assay as well as in vivo screening in the rat. The results of this study would provide a foundation for the development of functional foods or the identification of lead bioactive compounds or active ingredients against type 2 diabetes.

\section{Materials and methods}

\section{Chemicals and materials}

Acarbose, porcine pancreatic $\alpha$-amylase (PPA), and 2chloro-4-nitrophenyl- $\alpha$-D-maltotrioside (CNPG3) were obtained from Sigma-Aldrich (Germany). 2,2-Diphenyl1-picrylhydrazyl (DPPH) was purchased from Hi-media (India). Quercetin, dimethyl sulphoxide, sodium dihydrogen orthophosphate, starch, and other chemicals were purchased from Fisher Scientific (India).

\section{Collection of plant materials}

The leaves, fruit part, stem, bark, and roots of different plants were collected from different areas of Nepal during May-December, 2016. The plant samples were collected based on a review, such as the ethnomedicinal uses of Nepalese medicinal plants. None of these plants are endangered in Nepal. Collected plant samples were identified by the Department of Plant Resources, National Herbarium, Godawari, Ministry of Forests and Soil Conservation, Nepal.

\section{Preparation of extracts}

The collected plants were shade dried at room temperature by avoiding direct sunlight and pulverized. The powder of different plants was soaked in methanol for $24 \mathrm{~h}$, filtered by muslin cloth, and collected in a conical flask; the same process was repeated for three successive days with fresh methanol. Then the filtrates were again filtered through Whatman filter paper (No. 1) and were concentrated in a vacuum in a rotary evaporator at $50^{\circ} \mathrm{C}$.

\section{In vitro antioxidant assay}

The antioxidant activity was determined using DPPH as described previously [20] with slight modification. Briefly, $100 \mu \mathrm{L}$ of various concentrations of the extracts in $50 \%$ DMSO was added to $100 \mu \mathrm{L}$ of a $0.1 \mathrm{mM}$ sample of DPPH in methanol. After $30 \mathrm{~min}$ of incubation at room temperature in the dark, the absorbance was read at $517 \mathrm{~nm}$. The percentage of inhibition on the DPPH radical was calculated by using the following expression:

$$
\% \text { Inhibition }=100-\left(\frac{\text { OD of extract }}{\text { OD of control }}\right) \times 100
$$

Where optical density (OD) is the absorbance. The $\mathrm{IC}_{50}$ value was calculated using the EZ-Fit enzyme kinetics program (Perellela Scientific, Inc., Amherst, Mars, USA). 


\section{Assay for a-amylase}

The $\alpha$-amylase inhibition activity was evaluated in 50 $\mathrm{mM}$ phosphate buffer $\mathrm{pH} 7.0$ with $0.9 \% \mathrm{NaCl}$. The PPA at the final concentration of $1.5 \mathrm{units} / \mathrm{mL}$ (prepared in buffer mentioned above) with the various concentrations of test compounds (prepared in DMSO) was incubated at $37^{\circ} \mathrm{C}$ for $15 \mathrm{~min}$. The reaction was started by the addition of the substrate, CNPG3, at $375 \mu \mathrm{M}$ final concentration prepared in the buffer as above. The change in absorbance by released p-nitroaniline was continuously monitored at $405 \mathrm{~nm}$ [21]. The final concentration of DMSO was not more than $5 \%$ and was taken as control. All the experiments were performed in triplicate in a final volume of $200 \mu \mathrm{L}$, by using a microplate reader (Epoch2, BioTek, Instruments, Inc., USA).

The results were processed by using Gen 5 Microplate Data Collection \& Analysis Software and then by MS Excel. The percentage inhibition based upon initial velocity and was calculated as:

$$
\% \text { Inhibition }=100-\left(\frac{\mathrm{OD} / \text { minof extract }}{\mathrm{OD} / \text { minof control }}\right) \times 100
$$

$\mathrm{IC}_{50}$ (Inhibition of enzymatic hydrolysis of the substrate CNPG3 by 50\%) value was calculated using the EZ-Fit enzyme kinetics program.

\section{a-Amylase inhibition kinetics study}

The change in optical density per minute (OD/min) was determined by incorporating various concentrations of compounds over a range of substrate (CNPG3) concentrations between $0.187 \mathrm{mM}$ and $1.5 \mathrm{mM}$. Reciprocal of the rate of the reactions against the reciprocal of the substrate concentration as Lineweaver-Burk plot (and its secondary plot; slope versus compound concentration); the Dixon plot (and its secondary plot; slope versus reciprocal of compound concentration) [22-25]. Graphs were plotted using GraFit 4 (Erithacus Software Limited, Surrey, UK) and GraphPad Prism 5 (GraphPad Software, California, USA). The types of inhibition were determined by the comparison of $\mathrm{Km}$ and Vmax values of the substrate and their ratios $(\mathrm{Km} / \mathrm{Vmax})$ in the presence and absence of the inhibitors. The types of inhibition were also determined by graphical views of Dixon plots, Lineweaver-Burk plots, and their secondary plots. The $K_{i}$ values obtained directly from the software (GraFit 4 and GraphPad Prism 5), were also cross-checked and tallied in these graphs. The final concentration of DMSO was maintained at $5 \%$.

\section{In vivo oral starch tolerance test in non-diabetic rats (NDRs)}

Healthy Swiss albino rats (8 weeks old) weighing about $150-200 \mathrm{~g}$ were obtained from the Department of Plant
Resources, Kathmandu, Nepal. Oral starch tolerance tests in non-diabetic rats were done according to the method described previously [26] with slight modification. The rats were kept for acclimatization at an ambient temperature of $25 \pm 2{ }^{\circ} \mathrm{C}$ and $45-55 \%$ relative humidity, with $12 \mathrm{~h}$ alternation of dark and light cycles and were fed pelleted diet and tap water with free excess [26]. The protocol for this test was certified by the Department of Plant Resources, Animal Ethics Committee, Kathmandu, Nepal (DPR), with the ethical certificate number - 92/074/75.

In this test, 25 overnight-fasted $(12 \mathrm{~h})$ non-diabetic rats were divided into five groups of five rats each $(n=$ 5), oral doses of $250 \mathrm{mg} / \mathrm{kg}$ extracts dissolved in distilled water (group I, II and III), glibenclamide with an oral dose of $5 \mathrm{mg} / \mathrm{kg}$ (group IV) and distilled water as control (group V) were administered, respectively. After $30 \mathrm{~min}$, the rats were administered starch orally at a dose of $2 \mathrm{~g} /$ $\mathrm{kg}$ body weight, and blood was collected via tail puncture for blood glucose estimation before $(0 \mathrm{~min})$ and at 30, 60, and $120 \mathrm{~min}$ following starch treatment. Indeed, no rats during the experiment are purposely harmed, and handling of rats was carried out according to "the ethical guidelines based laboratory animals for research 1994" (National Regulations of Nepal).

\section{Statistical analysis}

The results are present as the mean \pm standard error of the mean of triplicate experiments. All data obtained were analyzed using analysis of variance (one-way ANOVA) and further analyzed by Dunnett's one side (less than control) comparison by SPSS software (version 19).

\section{Results}

\section{Screening of plant extracts for a-amylase inhibition}

A total of 32 plant extracts were selected for the study, and their crude extracts $(500 \mu \mathrm{g} / \mathrm{mL})$ were evaluated for the inhibitory activity against PPA (Table 1 ). The extracts, which showed over $50 \%$ inhibition, were considered for further study to maintain hit to lead rate at approximately $5 \%$.

\section{In vitro antioxidant assay}

DPPH (1, 1-diphenyl-2-picrylhydrazyl) radical scavenging assay was done to analyze the antioxidant capacities of the potent amylase inhibitor plants. Therefore, DPPH radical scavenging potential of the three extracts, which had exhibited strong $\alpha$-amylase inhibitory potential, was evaluated (Table 2). The results of DPPH radical scavenging were reported as $\mathrm{IC}_{50}$, which shows the concentrations of the samples, which scavenge 50\% DPPH radical. Table 2 reveals the $\mathrm{IC}_{50}$ value of three extracts and quercetin as a standard. 
Table 1 List of plants selected for the study of a-amylase inhibitory potentials of their methanolic extracts

\begin{tabular}{|c|c|c|c|c|c|}
\hline S.N. & Scientific Name & Local Name & Family & Inhibition $\mathbf{a}(\%)$ & Ethnobotanical use \\
\hline 1 & Abrus precatorius L. & Ratigedi & Fabaceae & $<50$ & {$[27]$} \\
\hline 2 & Acacia catechu (L.f.) Willd. & Khayar & Fabaceae & 89.9 & {$[17,28]$} \\
\hline 3 & Acorus calamus $\mathrm{L}$. & Bojho & Araceae & $<50$ & {$[29]$} \\
\hline 4 & Aegle marmelos (L.) Correa & Bel & Rutaceae & $<50$ & {$[27,30]$} \\
\hline 5 & Aloe vera (L.) Burm.f. & Gheukumari & Asphodelaceae & $<50$ & {$[27,31]$} \\
\hline 6 & Amomum subulatum Roxb. & Alachi & Zingiberaceae & $<50$ & {$[29]$} \\
\hline 7 & Azadirachta indica A. Juss. & Neem & Meliaceae & $<50$ & {$[17,27]$} \\
\hline 8 & Bauhinia variegata $\mathrm{L}$. & Koiralo & Fabaceae & $<50$ & [28] \\
\hline 9 & Berberis asiatica Roxb. ex DC. & Chutro & Berberidaceae & $<50$ & [30] \\
\hline 10 & Catharanthus roseus (L.) G. Don & Barmase & Apocynaceae & $<50$ & [31] \\
\hline 11 & Cinnamomum tamala (Buch. -Ham.) T. Nees \& Eberm. & Tejpat & Lauraceae & $<50$ & {$[29,30]$} \\
\hline 12 & Cleistocalyx operculatus (Roxb.) Merr. \& L.M.Perry & Kyaamuna & Myrtaceae & $<50$ & [28] \\
\hline 13 & Coccinia grandis (L.) Voigt & Kundru & Cucurbitaceae & $<50$ & [32] \\
\hline 14 & Dioscorea bulbifera L. & Bhyakur & Discoreaceae & 58.7 & {$[33]$} \\
\hline 15 & Ficus benghalensis $\mathrm{L}$. & Bar & Moraceae & $<50$ & {$[27,34]$} \\
\hline 16 & Ficus racemosa L. & Gular & Moraceae & $<50$ & {$[27,34]$} \\
\hline 17 & Ficus religiosa $\mathrm{L}$. & Peepal & Moraceae & $<50$ & [27] \\
\hline 18 & Girardinia diversifolia (Link) Friis & Chalne Sisno & Urticaceae & $<50$ & [35] \\
\hline 19 & Holoptelea integrifolia Roxb. Planch & Kanju, Sano Pangro & Ulmaceae & $<50$ & [36] \\
\hline 20 & Justicia adhatoda L. & Asuro & Acanthaceae & $<50$ & {$[27]$} \\
\hline 21 & Momordica charantia L. & Tite Karela & Cucurbitaceae & $<50$ & {$[27,32]$} \\
\hline 22 & Murraya koenigii L. Spreng. & Mitho Neem, Mechiya Saag & Rutaceae & $<50$ & [30] \\
\hline 23 & Nyctanthes arbortristis L. & Parijat & Oleaceae & $<50$ & [37] \\
\hline 24 & Ocimum tenuiflorum L. & Kalo tulsi & Lamiaceae & $<50$ & [27] \\
\hline 25 & Punica granatum $\mathrm{L}$. & Anar & Punicaceae & $<50$ & [27] \\
\hline 26 & Saraca asoca (Roxb.) Willd. & Ashok & Fabaceae & $<50$ & [36] \\
\hline 27 & Shorea robusta Gaertn. & Sal & Dipterocarpaceae & $<50$ & [28] \\
\hline 28 & Swertia chirata Buch.-Ham.ex Wall. & Chiraito & Gentianaceae & 63.5 & {$[28,38]$} \\
\hline 29 & Syzygium cumini (L.) Skeels & Fadel & Myrtaceae & $<50$ & [27] \\
\hline 30 & Tinospora sinensis (Lour.) Merr. & Gurjo & Menispermaceae & $<50$ & [17] \\
\hline 31 & Urtica parviflora Roxb. & Sisnoo & Urticaceae & $<50$ & [27] \\
\hline 32 & Zanthoxylum armatum DC. & Timur & Rutaceae & $<50$ & {$[30]$} \\
\hline
\end{tabular}

${ }^{\mathrm{a} A t} 500 \mu \mathrm{g} / \mathrm{mL}$

Table 2 a-Amylase inhibition $\left(\mathrm{IC}_{50}\right)$ and binding affinities of methanolic extracts $\left(\mathrm{K}_{\mathrm{i}}\right)$ and their DPPH radical scavenging (antioxidant) activities

\begin{tabular}{|c|c|c|c|c|}
\hline \multirow[b]{2}{*}{ Plant } & \multicolumn{3}{|c|}{ a-Amylase inhibition $(\mu \mathrm{g} / \mathrm{mL})$} & \multirow{2}{*}{$\begin{array}{l}\text { Antioxidant activity }(\mu \mathrm{g} / \mathrm{mL}) \\
I_{50} \text { value }\end{array}$} \\
\hline & $\mathrm{IC}_{50}$ value & $\mathrm{K}_{\mathrm{i}}$ value & Type of inhibition & \\
\hline Acacia catechu & $49.9 \pm 0.4$ & $26.6 \pm 6.7$ & Mixed & $3.9 \pm 0.3$ \\
\hline Dioscorea bulbifera & $413.5 \pm 11.1$ & $384.6 \pm 36.8$ & Mixed & $49.3 \pm 3.6$ \\
\hline Swertia chirata & $296.1 \pm 8.7$ & $204.2 \pm 17.9$ & Mixed & $53.6 \pm 2.7$ \\
\hline Acarbose $^{a}$ & $6.1 \pm 0.1$ & - & - & - \\
\hline Quercetin $^{b}$ & - & - & - & $2.3 \pm 0.1$ \\
\hline
\end{tabular}

Acarbose $^{\text {a }}$ was used as the standard for a-amylase inhibition Quercetin $^{\mathrm{b}}$ was used as the standard for radical scavenging activity 
In vitro and kinetic study of a-amylase enzyme

Table 2 reveals the $\mathrm{IC}_{50}$ value of potent three extracts, their inhibitor constant $\left(\mathrm{K}_{\mathrm{i}}\right)$, and mode of inhibition. The active extracts were investigated to find binding affinity and mechanism of inhibition of $\alpha$-amylase by kinetics study (Fig. 1 and Figure S2 (supporting data). The initial rate was measured at the different substrate and inhibitor concentrations in order to determine inhibition constants $\left(\mathrm{K}_{\mathrm{i}}\right)$ and the mode of reversible inhibition of PPA by methanolic extracts. Then the quest for a type of inhibition was done from the generated data among competitive, noncompetitive, or uncompetitive models - the Lineweaver-Burk plot, which revealed mixed-type inhibition. The kinetic behavior of CNPG3 at different concentrations of CNPG3 and methanolic extracts is shown in Fig. 1. The extracts act as a mixedtype inhibitor, and the values of inhibitor constant $\left(\mathrm{K}_{\mathrm{i}}\right)$ varied from 26.6 to $384.6 \mu \mathrm{g} / \mathrm{mL}$, respectively.

\section{In vivo assay in a mouse model}

A. catechu and S. chirata showed the reduction of blood glucose levels up to $30 \mathrm{~min}$ in in vivo study. Their efficacies were tested in rats as well for the glucose level reduction. The methanolic extracts of $A$. catechu and $S$. chirata reduce the glucose level up to $30 \mathrm{~min}[(\mathrm{~F}(5$, $25)=3.8, p=.048)$, and $(\mathrm{F}(5,25)=3.8, p=.029)]$, respectively. The crude extract of $D$. bulbifera failed to show its effectiveness in the rat (Supplementary file).

\section{Discussion}

The amylase activity monitoring methods such as starchiodine and dinitrosalicylic acid assay are labor-intensive, inconsistent, and include heating process, which makes the formation of insoluble clumps. With the help of a microplate reader, large samples can be evaluated simultaneously in the minimal interval; besides this accuracy, uniformity and reliability are some advantages of microplate reader assays [39-41]. The microtiter plate-based assay using CNPG3 is easy, rapid, and reliable [42].

In this work, 32 crude extracts were examined on PPA-catalyzed hydrolysis of CNPG3; among them, $A$. catechu, S. chirata and D. bulbifera had potent $\mathrm{IC}_{50}$ values ranging from 49.9 to $413.5 \mu \mathrm{g} / \mathrm{mL}$. In the previous study, the $\mathrm{IC}_{50}$ value of $A$. catechu ethanolic seed extract was noted to be $341.2 \pm 15.3 \mu \mathrm{g} / \mathrm{mL}$ [43], while the present study of methanolic extract was found to be $49.9 \mu \mathrm{g} / \mathrm{mL}$. Previously, the $\mathrm{IC}_{50}$ value of the methanolic extract of $S$. chirata was reported $52.4 \pm 0.4 \mu \mathrm{g} / \mathrm{mL}$ [44] as compared to $296.1 \pm 8.7 \mu \mathrm{g} / \mathrm{mL}$ in our study. Numerous factors such as degree of ripeness at the time of harvest, environmental factors, processing, and storage affect the polyphenol content of plants, which might be responsible for variation in the $\mathrm{IC}_{50}$ value of plants [45]. The $\mathrm{IC}_{50}$ value of the positive control acarbose $\left(\mathrm{IC}_{50}=\right.$ $6.1 \mu \mathrm{g} / \mathrm{mL}$ ) is less than plant extracts, but it is not surprising that the $\mathrm{IC}_{50}$ of extracts is high. The plant extracts are mixtures of numerous compounds as compared to single compound acarbose.

In plant extracts, compounds like dioscorin, sapogenins, choline, L-arginine, polysaccharides, and proteins might be the source of antidiabetic behaviors [46]. Catechin and epicatechin are the active ingredients in the $A$. catechu $[47,48]$, which have been identified as a potent inhibitor of $\alpha$-amylase [49, 50]. Swerchirin [51] could be the active ingredient in the $S$. chirata that plays the role of the inhibition of $\alpha$-amylase [52]. Diosgenin, the constituent of D. bulbifera might be responsible for the inhibition of PPA [33]. Hydrogen bonding between amino acids has been elucidated by molecular docking of catechin (Glu233, Arg195, His201, and Ile235 and Asp197) epicatechin (Glu233, Arg 195, His201, and Ile235 and Asp197) and diosgenin (Asp300) with $\alpha$-amylase. In
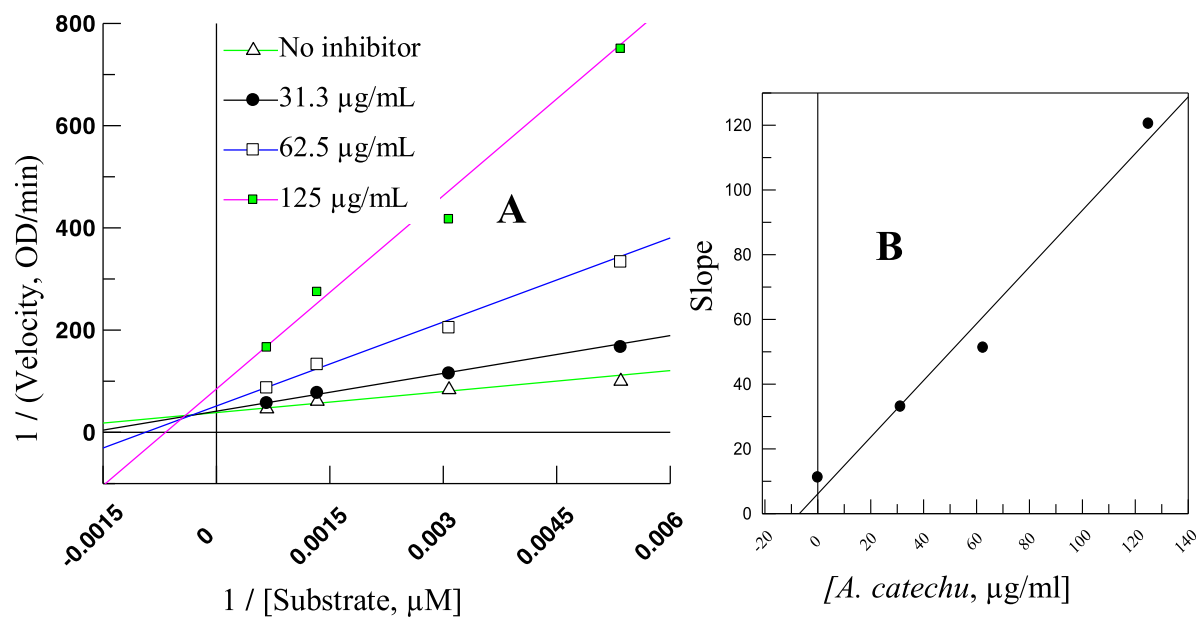

Fig. 1 a-Amylase inhibition kinetics study. a Line-weaver Burk plot of extracts of A. catechu. $\mathbf{b}$ The secondary plot of Line-weaver Burk plot 
addition to these, some amino acids also participated in hydrophobic bonding. In sum, hydrogen bonding and hydrophobic interactions could contribute to inhibit the activity of $\alpha$-amylase [33, 53].

From the Lineweaver-Burk Plot, Dixon plot, and their secondary plot, it is confirmed that the mode of inhibition is a mixed type. The inhibition constant $\left(K_{\mathrm{i}}\right)$ was calculated by GraFit 4 software and was confirmed by the secondary plot of Lineweaver-Burk and Dixon plot [22]. Kinetic study reveals that both EI and ESI complexes are formed in mixed-type inhibition, where all lines are intersected at the second quadrant on the Lineweaver-Burk plot and Dixon plot as shown in Fig. 1a and Figure S2(a) [54]. In mixed-type inhibition, the inhibitor can bind to both active site and non-active sites of the enzyme. The catalytic barrel and non-catalytic Cterminal domains of barley $\alpha$-amylase contain two secondary carbohydrate-binding sites which have been assumed to exist on other amylases $[55,56]$.

Glibenclamide releases endogenous insulin by cytosolic depolarization caused due to selective blockade of ATP sensitive $\mathrm{K}^{+}$channels in the plasma membrane of $\beta$-cells of the pancreas showing antihyperglycemic activity in diabetic mice [57]. Similarly, plant extracts also act either by tonic liberation of insulin by $\beta$-cells of islets of Langerhans or by impeding certain enzymes responsible for increasing blood glucose levels in mice [58]. The allantoin compound isolated from Dioscorea spp. significantly reduce plasma glucose in streptozotocin-induced diabetic rats [59]. The previous study has shown that diosgenin failed to show its effectiveness in either normal or streptozocin induced diabetic mice [60]. Therefore, D. bulbifera may contain diosgenin but may not contain allantoin, which might be the reason for its failure in mice.

Clinical and experimental evidence support that cellular oxidative stress occurred as a result of the generation of reactive oxygen species and reduced antioxidant potential could enhance diabetic complications [61-63]. The number of studies has shown that oxidative stress is assumed as a major cause of pancreatic cell death and its relationship in $\beta$-cell loss or apoptosis [64]. Recently, antioxidant therapy is employed for the remedy and control of diabetes [65].

All three plants, which were the most potential inhibitor of amylase enzyme in our study, i.e., Acacia catechu, Dioscorea bulbifera, and Swertia chirata are easily available and gaining attention for commercial production with high yield rate.

A. catechu grows well in the degraded lands and popular in choice of community plantations in Nepal because it is used as fuelwood, small timber and fodder as well as kathha and other pharmacological uses [66]. A. catechu was found a second-best plant for commercial production in a research conducted in a district of Terai region of Nepal [67]. A total of 1158 tons (worth 690 Million NPR) of Khair Kathha extracted from A. catechu was exported from Nepal in the year 2017 [68].

Swertia chirata was one of the most exported plants from a District of Nepal [69]. D. bulbifera is one of the major food in some of the ethnic groups of Nepal and has been cultivating widely [70].

The crude extract contains several bioactive compounds; therefore, we need to investigate for the fully characterized molecule, which may be a potent enzyme inhibitor.

\section{Conclusion}

The microtiter plate-based assay using extracts of the medicinal plant is successfully evaluated for $\alpha$-amylase inhibition assays. The present study demonstrated that the traditionally used medicinal plants by local people to manage diabetes might contain certain ingredients that inhibit $\alpha$-amylase. The kinetic analysis demonstrates that inhibition is that of mixed type for plants extract with porcine $\alpha$-amylase, and shows that extracts might serve as potential candidates for future drug development strategies. This study aimed to provide a scientific basis for the pre-existing ethnobotanical use of medicinal plants by selecting potential candidate plants with higher antidiabetic properties.

\section{Supplementary information}

Supplementary information accompanies this paper at https://doi.org/10. 1186/s40816-020-00179-8.

\section{Additional file 1.}

Abbreviations

PPA: Porcine pancreatic a-amylase; CNPG3: 2-chloro-4-nitrophenyl-a-Dmaltotrioside; DPPH: 2,2-diphenyl-1-picrylhydrazyl; OD: Optical density

\section{Acknowledgements}

We thank National Herbarium and Plant Laboratory, Ministry of Forest and Soil Conservation, Nepal, for the identification of plant species. We are grateful to Mr. Rajeshwor Ranjitkar (Department of Plant Resources, Nepal) for surveillance and assisting us with all the animal experiments.

\section{Authors' contributions}

N.P. and B.P.M. designed research; K.K., S.G., and H.G. performed research; B.P.M. contributed analytical tools; N.P. and B.P.M. analyzed data, and B.P.M. and K.K. wrote the paper. The author(s) read and approved the final manuscript.

\section{Funding}

This work was financially supported by TWAS (The World Academy of Science-15-227 RG/CHE/AS_G - FR3240287027), and the higher education reform project, Nepal to Niranjan Parajuli.

\section{Availability of data and materials}

Herbaria of plant specimens and the identification information sheets are stored in the laboratory and can be retrieved when necessary. Data supporting this manuscript are protected in laboratory information systems at our institution and are available from the corresponding author on reasonable request. 


\section{Ethics approval and consent to participate}

Experiment related to animals was executed at the Department of Plant Resources, Natural Products Research Laboratory, Government of Nepal, based on the ethical guidelines provided by the Department for Nepal.

\section{Consent for publication}

The consent to publish the results of animal experiments was provided by the Department of Plant Resources, Natural Products Research Laboratory Government of Nepal. We also declared that there no conflict of interest among authors to publish these research findings.

\section{Competing interests}

The authors declare that they have no competing interests.

\section{Author details}

'Department of Biotechnology, National College, Tribhuvan University, Naya Bazar, Kathmandu, Nepal. ${ }^{2}$ Central Department of Chemistry, Tribhuvan University, Kirtipur, Kathmandu, Nepal.

\section{Received: 24 December 2019 Accepted: 20 May 2020 \\ Published online: 28 May 2020}

\section{References}

1. International Diabetes Federation. IDF diabetes atlas. 9th ed; 2019

2. World Health Organization. Definition and diagnosis of diabetes mellitus and intermediate hyperglycaemia: report of a WHO/IDF consultation; 2006.

3. American Diabetes Association. Diagnosis and classification of diabetes mellitus. Diabetes Care. 2014;37(Supplement 1):S81-90.

4. World Health Organization. Global report on diabetes, vol. 978; 2016. p. 88

5. Imam SK. Diabetes: a new horizon and approach to management. In: Glucose intake and utilization in pre-diabetes and diabetes UK: Elsevier Academic press; 2015. p. 29-44.

6. Anitha Gopal B, Muralikrishna G. Porcine pancreatic a-amylase and its isoforms: purification and kinetic studies. Int J Food Prop. 2009:12(3):571-86.

7. Janeček Š, Baláž Š. a-Amylases and approaches leading to their enhanced stability. FEBS Lett. 1992:304(1):1-3.

8. Pasero L, Mazzéi-Pierron Y, Abadie B, Chicheportiche Y, Marchis-Mouren G. Complete amino acid sequence and location of the five disulfide bridges in porcine pancreatic a-amylase. Biochim Biophys Acta (BBA)-Protein Struct Molec Enzym. 1986:869(2):147-57.

9. Kazeem MI, Adamson JO, Ogunwande IA. Modes of inhibition of a-amylase and a-glucosidase by aqueous extract of Morinda lucida Benth leaf. Biomed Res Int. 2013:2013:1.

10. Chaudhury A, Duvoor C, Dendi R, Sena V, Kraleti S, Chada A, et al. Clinical review of antidiabetic drugs: implications for type 2 diabetes mellitus management. Front Endocrinol. 2017;8:6.

11. Kumar S, Narwal S, Kumar V, Prakash O. a-Glucosidase inhibitors from plants: a natural approach to treat diabetes. Pharmacogn Rev. 2011;5(9):19.

12. Hsieh $\mathrm{SH}$, Shih $\mathrm{KC}$, Chou $\mathrm{CW}$, Chu CH. Evaluation of the efficacy and tolerability of miglitol in Chinese patients with type 2 diabetes mellitus inadequately controlled by diet and sulfonylureas. Acta Diabetol. 2011;48(1): $71-7$.

13. Ali H, Houghton PJ, Soumyanath A. a-Amylase inhibitory activity of some Malaysian plants used to treat diabetes; with particular reference to Phyllanthus amarus. J Ethnopharmacol. 2006;107(3):449-55.

14. Subhedar S, Goswami P. Ethnobotany and literature survey of herbal antidiabetic drugs. Int J Drug Discov Herbal Res. 2011;1(3):177-84.

15. Mojica L, Meyer A, Berhow MA, de Mejía EG. Bean cultivars (Phaseolus vulgaris $\mathrm{L}$.) have similar high antioxidant capacity, in vitro inhibition of aamylase and a-glucosidase while diverse phenolic composition and concentration. Food Res Int. 2015;69:38-48.

16. Udani J, Hardy M, Madsen DC. Blocking carbohydrate absorption and weight loss: a clinical trial using phase $2^{\mathrm{TM}}$ brand proprietary fractionated white bean extract. Altern Med Rev. 2004;9(1):63-9.

17. Kunwar RM, Shrestha KP, Bussmann RW. Traditional herbal medicine in farWest Nepal: a pharmacological appraisal. J Ethnobiol Ethnomed. 2010;6(1): 35.

18. Adhikari M, Thapa R, Kunwar RM, Devkota HP, Poudel P. Ethnomedicinal uses of plant resources in the Machhapuchchhre rural municipality of Kaski District, Nepal. Medicines. 2019;6(2):69.
19. American Diabetes Association. Classification and diagnosis of diabetes. Sec. 2. In standards of medical care in diabetes -2015. Diabetes Care. 2015;38: S8-16.

20. Brand-Williams W, Cuvelier ME, Berset CL. Use of a free radical method to evaluate antioxidant activity. LWT-Food Sci Technol. 1995;28(1):25-30.

21. Senger MR, Gomes LD, Ferreira SB, Kaiser CR, Ferreira VF, Silva FP Jr. Kinetics studies on the inhibition mechanism of pancreatic a-amylase by Glycoconjugated 1H-1, 2, 3-Triazoles: a new class of inhibitors with Hypoglycemiant activity. ChemBioChem. 2012;13(11):1584-93.

22. Marasini BP, Rahim F, Perveen S, Karim A, Khan KM, Choudhary MI. Synthesis, structure-activity relationships studies of benzoxazinone derivatives as a-chymotrypsin inhibitors. Bioorg Chem. 2017;70:210-21.

23. Lineweaver $H$, Burk $D$. The determination of enzyme dissociation constants. J Am Chem Soc. 1934;56(3):658-66.

24. Dixon M. The determination of enzyme inhibitor constants. Biochem J. 1953;55(1):170.

25. Segel $\Vdash H$. Enzyme kinetics: behavior and analysis of rapid equilibrium and steady state enzyme systems. Hoboken: Wiley; 1993.

26. Ali RB, Atangwho IJ, Kuar N, Ahmad M, Mahmud R, Asmawi MZ. In vitro and in vivo effects of standardized extract and fractions of Phaleria macrocarpa fruits pericarp on lead carbohydrate digesting enzymes. BMC Complement Altern Med. 2013;13(1):39.

27. Joshi K. Ethnobotanical study of plants used for the treament of diabetes mellitus in the mountainous regions of Nepal. J Non-timber For Prod. 2011; 18(1):19-26.

28. Shrestha P, Jamarkattel-Pandit N. Survey on medicinal plants used for antidiabetic activity in Kaski District, Nepal. JHAS. 2018;7(1):1-7.

29. Singh AG. 9. Ethnomedicinally important plants used as spices and condiments in the rupandehi district, West Nepal by Anant gopal singh. Life Sci Leaflets. 2017:85:64-71.

30. Kunwar RM, Uprety Y, Burlakoti C, Chowdhary CL, Bussmann RW. Indigenous use and ethnopharmacology of medicinal plants in far-West Nepal. Ethnobot Res Appl. 2009;7:005-28.

31. Rai SK. Medicinal plants used by Meche people of Jhapa district, eastern Nepal. Nature. 2004;2(1):27-32.

32. Singh AG, Kumar A. Ethnomedicinal aspects of climbing plants of Palpa district, Nepal. Trop Plant Res. 2017;4(2):307-13.

33. Ghosh $\mathrm{S}$, More P, Derle A, Patil AB, Markad P, Asok A, et al. Diosgenin from Dioscorea bulbifera: novel hit for treatment of type II diabetes mellitus with inhibitory activity against a-amylase and a-glucosidase. PLoS One. 2014;9(9): e106039.

34. Kunwar RM, Bussmann RW. Ficus (fig) species in Nepal: a review of diversity and indigenous uses. Lyonia. 2006;11(1):85-97.

35. Malla B, Gauchan DP, Chhetri RB. Medico-ethnobotanical investigations in Parbat district of Western Nepal. J Med Plant Res. 2014;8(2):95-108.

36. Medicinal plants of Nepal. Bulletin of Department of Plant Resources (DPR): Thapathali, Kathmandu, Nepal. 2nd ed; 2016.

37. Singh AG, Kumar A, Tewari DD, Bharati KA. New ethnomedicinal claims from Magar community of Palpa district. Nepal Indian J Tradit Knowl. 2018; 17(3):499-511.

38. Rai MB. Medicinal plants of Tehrathum district, eastern Nepal. Nature. 2003: 1(1):42-8.

39. Oliveira HM, Pinheiro AQ, Fonseca AJ, Cabrita AR, Maia MR. Flexible and expeditious assay for quantitative monitoring of alpha-amylase and amyloglucosidase activities. MethodsX. 2019:6:246-58.

40. Xiao Z, Storms R, Tsang A. A quantitative starch iodine method for measuring alpha-amylase and glucoamylase activities. Anal Biochem. 2006; 351(1):146-8

41. Pimstone NR. A study of the starch-iodine complex: a modified colorimetric micro determination of amylase in biologic fluids. Clin Chem. 1964;10(10): 891-906.

42. Cybulski RL, inventor; Dade International Inc, assignee. Method for eliminating hemolysis interference in an amylase analysis. United States patent US 5,766,872. 1998 Jun 16.

43. Lakshmi T, Ramasamy R, Thirumalaikumaran R. Preliminary phytochemical analysis and In vitro antioxidant, FTIR spectroscopy, anti-diabetic activity of Acacia catechu ethanolic seed extract. Phcog J. 2015;7:6.

44. Roy P, Abdulsalam FI, Pandey DK, Bhattacharjee A, Eruvaram NR, Malik T. Evaluation of antioxidant, antibacterial, and antidiabetic potential of two traditional medicinal plants of India: Swertia cordata and Swertia chirayita. Pharm Res. 2015;7(Suppl 1):S57. 
45. Manach C, Scalbert A, Morand C, Rémésy C, Jiménez L. Polyphenols: food sources and bioavailability. Am J Clin Nutr. 2004;79(5):727-47.

46. Go HK, Rahman M, Kim GB, Na CS, Song CH, Kim JS, et al. Antidiabetic effects of yam (Dioscorea batatas) and its active constituent, allantoin, in a rat model of streptozotocin-induced diabetes. Nutrients. 2015;7(10): 8532-44.

47. Duval A, Averous L. Characterization and physicochemical properties of condensed tannins from Acacia catechu. J Agric Food Chem. 2016;64(8): 1751-60.

48. Shen D, Wu Q, Wang M, Yang Y, Lavoie EJ, Simon JE. Determination of the predominant catechins in Acacia catechu by liquid chromatography/ electrospray ionization- mass spectrometry. J Agric Food Chem. 2006;54(9): 3219-24.

49. Hara Y, Honda M. The inhibition of a-amylase by tea polyphenols. Agric Biol Chem. 1990:54(8):1939-45.

50. Yilmazer-Musa M, Griffith AM, Michels AJ, Schneider E, Frei B. Inhibition of aamylase and a-glucosidase activity by tea and grape seed extracts and their constituent catechins. J Agric Food Chem. 2012;60(36):8924.

51. Ghosal S, Sharma PV, Chaudhuri RK, Bhattacharya SK. Chemical constituents of the gentianaceae V: Tetraoxygenated xanthones of Swertia chirata buch.ham. J Pharm Sci. 1973;62(6):926-30.

52. Bajpai MB, Asthana RK, Sharma NK, Chatterjee SK, Mukherjee SK. Hypoglycemic effect of swerchirin from the hexane fraction of Swertia chirayita. Planta Med. 1991;57(02):102-4.

53. Choudhary DK, Mishra A. In vitro and in silico interaction of porcine aamylase with Vicia faba crude seed extract and evaluation of antidiabetic activity. Bioengineered. 2017;8(4):393-403.

54. Cornish-Bowden A. A simple graphical method for determining the inhibition constants of mixed, uncompetitive and non-competitive inhibitors. Biochem J. 1974;137(1):143.

55. Nielsen MM, Seo ES, Bozonnet S, Aghajari N, Robert X, Haser R, et al. Multisite substrate binding and interplay in barley a-amylase 1. FEBS Lett. 2008; 582(17):2567-71.

56. Nielsen MM, Bozonnet S, Seo ES, Mótyán JA, Andersen JM, Dilokpimol A, et al. Two secondary carbohydrate binding sites on the surface of barley aamylase 1 have distinct functions and display synergy in hydrolysis of starch granules. Biochemistry. 2009;48(32):7686-97.

57. Tomai F, Crea F, Gaspardone A, Versaci F, De Paulis R. Penta de Peppo a, Chiariello L, Gioffrè PA. Ischemic preconditioning during coronary angioplasty is prevented by glibenclamide, a selective ATP-sensitive K+ channel blocker. Circulation. 1994;90(2):700-5.

58. Doyle ME, Egan JM. Pharmacological agents that directly modulate insulin secretion. Pharmacol Rev. 2003;55(1):105-31.

59. Niu CS, Chen W, Wu HT, Cheng KC, Wen YJ, Lin KC, et al. Decrease of plasma glucose by allantoin, an active principle of yam (Dioscorea spp.), in streptozotocin-induced diabetic rats. J Agric Food Chem. 2010;58(22); 12031-5.

60. Kato A, Miura T, Fukunaga T. Effects of steroidal glycosides on blood glucose in normal and diabetic mice. Biol Pharm Bull. 1995;18(1): 167-8.

61. Baynes JW, Thorpe SR. Role of oxidative stress in diabetic complications: a new perspective on an old paradigm. Diabetes. 1999;48(1):1-9.

62. Son SM, Whalin MK, Harrison DG, Taylor WR, Griendling KK. Oxidative stress and diabetic vascular complications. Curr Diab Rep. 2004;4(4): 247-52.

63. Modak M, Dixit P, Londhe J, Ghaskadbi S, Devasagayam TP. Recent advances in Indian herbal drug research guest editor: Thomas Paul Asir Devasagayam Indian herbs and herbal drugs used for the treatment of diabetes. J Clin Biochem Nutr. 2007:40(3):163-73.

64. Sakurai K, Katoh M, Someno K, Fujimoto Y. Apoptosis and mitochondrial damage in INS-1 cells treated with alloxan. Biol Pharm Bull. 2001;24(8):876-82.

65. Van Doan H, Riyajan S, lyara R, Chudapongse N. Antidiabetic activity, glucose uptake stimulation and a-glucosidase inhibitory effect of Chrysophyllum cainito L. stem bark extract. BMC Complement Altern Med. 2018;18(1):1-10.

66. Jha P, Mandal RA. Assessment of growth performance of Acacia catechu. IJARB. 2019:5(1):34-8.

67. Thapa HB. Growth of five fast growing tree species in the Terai of eastern Nepal. Banko Janakari. 1998:8(2):14-22.
68. Rajendra KC. Contribution of NWFPs in National Economy. Banko Janakari. 2018;28(2):1-2.

69. Olsen CS, Helles F. Medicinal plants, markets, and margins in the Nepal Himalaya: trouble in paradise. Mt Res Dev. 1997;17(4):363-74.

70. Bhandari MR, Kasai T, Kawabata J. Nutritional evaluation of wild yam (Dioscorea spp.) tubers of Nepal. Food Chem. 2003:82(4):619-23.

\section{Publisher's Note}

Springer Nature remains neutral with regard to jurisdictional claims in published maps and institutional affiliations.

\section{Submit your manuscript to a SpringerOpen ${ }^{\circ}$ journal and benefit from:}

- Convenient online submission

- Rigorous peer review

- Open access: articles freely available online

- High visibility within the field

- Retaining the copyright to your article

Submit your next manuscript at $\boldsymbol{\nabla}$ springeropen.com 